\title{
Penggunaan Karungut Dalam Pembelajaran Kimia Serta Pendidikan Karakter Peserta Didik
}

(Pengembangan dan Penerapan Media, Instrumen dan Model Pembelajaran dalam Pendidikan Sains)

\author{
Arief Endit Prasetyo \\ SMA Muhammadiyah Kasongan, Katingan, Katingan \\ nd1tnt1@gmail.com
}

\begin{abstract}
Abstrak. Pendidikan karakter harus berakar dari budaya bangsa yang banyak melahirkan nilai atau kearifan. Khazanah budaya bangsa yang beragam, memberikan implikasi setiap masyarakat memiliki budaya lokal yang berbeda sehingga melahirkan kearifan lokal. Namun demikian, kearifan lokal melahirkan nilai-nilai yang realtif sama seperti tanggung jawab, kerjasama, toleransi dan lain-lain. Pembelajaran menggunakan karungut, mengimplementasikan penggunaan karungut dalam media pembelajaran dalam menghapalkan unsur-unsur dalam tabel periodik. Lagu yang digunakan dalam unsur-unsur tabel periodik, di terjemahkan dalam bahasa dayak dohoi sesuai dengan tempat peneliti mengajar. Setelah diterjemahkan, teks karungut tersebut di nyanyikan oleh alumni dari sekolah tempat penelitian yang menguasai kesenian karungut dan di dokumentasikan dalam bentuk video. Sumber daya lokal yang di implementasikan dalam pembelajaran kimia serta pendidikan karakter peserta didik berupa video karungut tentang unsur-unsur tabel periodik. Peserta didik lebih antusias dalam pembelajaran serta melestarikan kebudayaan lokal
\end{abstract}

Kata Kunci : karungut, pendidikan karakter, pembelajaran kimia

\section{Pendahuluan}

Pendidikan adalah suatu proses pembinaan guna mengantarkan peserta didik menemukan kediriannya. Artinya, pendidikan dimaksudkan untuk membentuk diri seseorang dalam hal ini siswa, agar menjadi manusia dewasa dan matang. Baik sebagai pribadi maupun anggota masyarakat. Undang-Undang Nomor 20 tahun 2003 tentang Sistem Pendidikan Nasional Bab I Ketentuan Umum, pasal 1 butir 1, menyebutkan bahwa pendidikan adalah usaha sadar dan terencana untuk mewujudkan suasana belajar dan proses pembelajaran agar peserta didik secara aktif mengembangkan potensi dirinya untuk memiliki kekuatan spiritual keagamaan, pengendalian diri, kepribadian, kecerdasan, akhlak 
mulia, serta ketrampilan yang diperlukan dirinya, masyarakat, bangsa dan negara.

Dasar, Fungsi dan Tujuan, yang pada pasal 2 disebutkan bahwa Pendidikan nasional berdasarkan pada Pancasila dan UUD 1945. Fungsinya untuk mengembangkan kemampuan dan membentuk watak serta peradaban bangsa yang bermartabat dalam rangka mencerdaskan kehidupan bangsa. Sedangkan tujuannya untuk mengembangkan potensi peserta didik agar menjadi manusia yang beriman dan bertaqwa kepada Tuhan Yang Maha Esa, berakhlak mulia, sehat, berilmu, cakap, kreatif, mandiri dan menjadi warga negara yang demokratis serta bertanggung-jawab Pada Bab III tentang prinsip penyelenggaraan pendidikan pasal 4 butir 1 dikatakan bahwa pendidikan diselenggarakan secara demokratis dan berkeadilan serta tidak diskriminatif dengan menjunjung tinggi hak asasi manusia, nilai keagamaan, nilai kultural dan kemajemukan bangsa (Wiji Suwarno, 2006, p. 32)

Berbagai upaya dalam mengatasi masalah pendidikan yang mencakup semua komponen pendidikan meliputi pembaharuan kurikulum, proses belajar mengajar, peningkatan kualitas guru, pengadaan buku pengajaran, sarana belajar, penyempurnaan sistem penilaian, dan usaha-usaha yang berkenaan dengan peningkatan kualitas pendidikan.

Ilmu kimia merupakan ilmu pengetahuan dasar bagi perkembangan ilmu pengetahuan dan teknologi. Oleh karena itu, penguasaan kimia harus diperbaharui agar mampu mengikuti dan mengembangkan IPTEK ke arah yang lebih baik. Untuk tujuan tersebut, maka pengajaran kimia harus bersifat dinamis dalam mengantisipasi perkembangan IPTEK yang semakin pesat.

“Tujuan pengajaran ilmu kimia di Sekolah Menengah Atas adalah agar siswa dapat 1) menguasai konsep-konsep kimia esensial secara komprehensif dan proses ilmiah untuk meningkatkan kesadaran akan ilmu pengetahuan dan teknologi dan kesadaran lingkungan, serta penerapannya dalam kehidupan sehari-hari, 2) mampu menerapkan konsep-konsep, prinsip-prinsip, teori-teori, maupun hukum-hukum dalam ilmu kimia yang relevan untuk memecahkan masalah-masalah dalam kehidupan sehari-hari yang ada disekitarnya, 3) memiliki ketrampilan-ketrampilan proses sains dan sikap-sikap ilmiah yang berlandaskan logika untuk memecahkan masalah-masalah serta menyadari kebesaran dan kekuasaan Tuhan Yang Maha Esa" (Depdiknas, 2003, hal. 1).

Berdasarkan tujuan yang diuraikan di atas dapat disimpulkan bahwa yang menjadi dasar pengajaran kimia adalah siswa dapat menguasai konsep-konsep 
kimia, bersikap ilmiah, serta dapat menerapkan konsep-konsep tersebut dalam kehidupan sehari-hari maupun teknologi. Oleh karena itu, maka penguasaan konsep-konsep kimia dan saling keterkaitannya merupakan bagian terpenting dalam proses belajar mengajar. Penyempurnaan dan peningkatan dalam proses belajar mengajar bertujuan untuk mendapatkan hasil belajar atau prestasi belajar yang baik.

\section{Pendidikan Karakter}

Pendidikan karakter pada dasarnya adalah pendidikan budi pekerti dengan cara menanamkan nilai-nilai moral kepada peserta didik. Nilai adalah sesuatu yang kita iakan atau kita aminkan. Nilai selalu mempunyai konotasi positif. Nilai moral merupakan nilai tertinggi. Nilai moral memiliki ciri-ciri (1) berkaitan dengan pribadi manusia yang bertanggung jawab, (2) berkaitan dengan hati nurani, (3) mewajibkan manusia secara absulut yang tidak bisa ditawar-tawar, dan (4) bersifat formal. Nilai moral berkaitan juga dengan apa yang seyogianya tidak dilakukan karena berkaitan dengan prinsip moralitas yang ditegakkan (Wiramihardja, 2007, p. 158). Hal itu mengacu juga pada Soejadi, (1999, p. 21) yang mengartikan nilai dalam arti baik atau benar berkaitan dengan masalah etis atau moral.

Lebih lanjut Scheler dalam Magnis-Suseno (2008, pp. 16-18) menyatakan bahwa nilai bersifat apriori. Maksudnya, apa arti sebuah nilai, misalnya enak, jujur atau kudus, kita ketahui bukan karena suatu pengalaman, secara aposteriori, melainkan kita ketahui begitu kita sadar akan nilai itu. Manusia tidak menciptakan nilai-nilai, melainkan menemukan mereka. Menurut Scheler nilai dapat diungkap bukan dengan pikiran, melainkan dengan suatu perasaan intensional. Perasaan di sini tidak dibatasi pada perasaan fisik atau emosi, melainkan mirip dengan paham rasa dalam budaya Jawa, sebagai keterbukaan hati dan budi dalam semua dimensi. Perasaan itu intensional karena setiap nilai ditangkap melalui perasaan yang terarah tepat padanya. Menurut Scheler ada empat gugus nilai, yaitu (1) nilai-nilai sekitar yang enak dan yang tidak enak, (2) nilai-nilai vital di mana paling utama adalah nilai yang luhur dan yang hina dan di mana saja termasuk keberanian dan sifat takut, perasaan sehat dan tidak enak badan, dan sebagainya, (3) nilai-nilai rohani yang indah dan yang jelek atau nilai estetis, nilai-nilai yang benar dan tidak benar atau nilai keadilan, dan nilai kebenaran murni yaitu kebernilaian pengetahuan demi pengetahuan itu sendiri dan bukan karena ada manfaatnya, dan (4) nilai-nilai sekitar yang kudus dan yang profane yang dihayati manusia dalam pengalaman religius. Di luar empat gugus 
nilai tersebut, ada dua gugus nilai yang tidak mempunyai isi sendiri (nilainya ditentukan oleh nilai yang menjadi tujuan akhir), yaitu nilai kegunaan dan nilai moral. Nilai kegunaan menunjuk pada sesuatu itu bernilai jika berguna dan nilai moral seperti yang baik dan yang jahat.

Konsep kata "baik" dapat dilihat dari berbagai pandangan. George Rdward Moore dalam Magnis-Suseno, (2008, pp. 1-3) mengatakan, kata "baik" adalah kata kunci moralitas. Kata "baik" merupakan kata dasar yang tidak dapat direduksikan kepada sesuatu yang lebih mendalam lagi. "Baik" merupakan sifat primer yang tidak terdiri atas bagian-bagian lagi, dan karena itu tidak dapat dianalisis. Kata "baik" kebalikan dari adalah "buruk". Tentang moral, Frans Magnis-Suseno (1987, p. 14) menjelaskan ajaran moral dimaksud adalah ajaran-ajaran, wejangan-wejangan, khotbah-khotbah, patokan-patokan, kumpulan peraturan dan ketetapan entah lisan atau tertulis, tentang bagaimana manusia harus hidup dan bertindak agar ia menjadi manusia yang baik. Sumber langsung ajaran moral adalah pelbagai orang dalam kedudukan yang berwenang, seperti orang tua dan guru, para pemuka masyarakat dan agama, dan tulisan-tulisan para bijak seperti kitab Wulangreh karangan Siri Sunan Paku Duwana IV. Sumber dalam ajaran-ajaran itu adalah tradisi dan adat istiadat, ajaran agama, atau ideologi tertentu.

Selanjutnya, Frans Magnis-Susena (1987, p. 19) menjelaskan kata moral selalu mengacu pada baik-buruknya manusia sebagai manusia. Jadi bukan mengenai baik-buruknya begitu saja, misalnya sebagai dosen, tukang masak, pemain bulutangkis atau penceramah, melainkan sebagai manusia. Bidang moral adalah bidang kehidupan manusia dilihat dari segi kebaikannya sebagai manusia. Norma-norma moral adalah tolok ukur untuk menentukan betul-salahnya sikap dan tindakan manusia dilihat dari segi baik-buruknya sebagai manusia dan bukan sebagai pelaku peran tertentu dan terbatas. Norma umum ada tiga macam, yaitu: norma-norma sopan-santun, norma-norma hukum, dan norma-norma moral. Norma sopan-santun menyangkut sikap lahiriyah manusia. Norma hukum adalah norma-norma yang dituntut dengan tegas oleh masyarakat karena dianggap perlu demi keselamatan dan kesejahteraan umum. Norma moral adalah tolok ukur yang dipakai masyarakat untuk mengukur kebaikan seseorang.

\section{Pembelajaran Kimia}

Pembelajaran sebagai pengajaran yang mempunyai arti cara (pembuatan) mengajar atau mengajarkan (Poerwadarminta, 1976, hal. 22). Subyek pembelajaran terdiri dari dua komponen, yaitu pengajar dan pebelajar. Nana 
Sudjana (1987, hal. 7) mengatakan pembelajaran sangat ditentukan oleh lingkungan yaitu mengatur dan mengorganisasikan lingkungan yang ada di sekitar siswa sehingga dapat mendorong dan menumbuhkan siswa melakukan kegiatan belajar. Gagne \& Briggs menyatakan dalam Gredler (1991, hal. 205)., "pembelajaran dilukiskan sebagai upaya orang yang tujuannya ialah membantu orang belajar". Alvin W. Howard dalam Slameto (1995, hal. 32) "pembelajaran adalah suatu aktivitas untuk mencoba menolong, membimbing seseorang untuk mendapatkan, mengubah atau mengembangkan keterampilan, sikap, cita-cita, penghargaan dan pengetahuan” Menurut Mursell dalam Slameto (1995, hal. 32) pembelajaran digambarkan sebagai "mengorganisasikan belajar", sehingga dengan mengorganisasikan itu, belajar menjadi lebih berarti atau bermakna bagi siswa.

"Pembelajaran adalah usaha sadar dan disengaja oleh guru untuk membuat siswa belajar dengan jalan mengaktifkan faktor ekstern dan faktor intern dalam kegiatan belajar mengajar" (Gino, 1997, hal. 32). Kegiatan belajar mengajar adalah kegiatan di mana terjadi interaksi antara pebelajar dan pengajar dalam upaya penyampaian suatu pengetahuan atau informasi. Adapun komponen kegiatan belajar mengajar adalah: a) Pebelajar adalah seseorang yang bertindak sebagai pencari, penerima, dan penyerap isi pelajaran yang dibutuhkan untuk mencapai tujuan pembelajaran, b) Pengajar adalah seseorang yang memberikan pelajaran kepada siswa, yang mempunyai fungsi sebagai pengelola kegiatan belajar mengajar dan sebagai katalisator, c) Tujuan yaitu pernyataan tentang perubahan penilaian yang diinginkan terjadi pada pebelajar setelah mengikuti belajar mengajar yang meliputi aspek kognitif, afektif, dan psikomotorik, c) Isi yang berupa informasi tentang fakta, prinsip, dan konsep yang diperlukan untuk mencapai tujuan, d) Metode, yaitu cara yang teratur untuk memberikan kesempatan kepada siswa untuk mendapatkan informasi yang dibutuhkan mereka untuk mencapai tujuan, e) Media, berupa bahan pengajaran yang digunakan untuk menyajikan informasi kepada siswa untuk mencapai tujuan, f) Evaluasi yang berisi cara untuk menilai keberhasilan proses belajar mengajar.

Mata pelajaran Kimia merupakan mata pelajaran wajib bagi siswa yang telah mengambil jurusan Ilmu Alam, hal ini tidak menutup kemungkinan akan adanya kesulitan dalam mengikuti pembelajarannya. Selain itu, pada umumnya siswa sudah menganggap bahwa mata pelajaran Kimia menakutkan dan membosankan, akibatnya tidak sedikit siswa yang kurang bahkan tidak tertarik dalam memahami dan menguasai konsep-konsep dasar pada materi kimia.

Menurut Mulyati Arifin (1995, hal. 220), kesulitan siswa dalam 
mempelajari ilmu kimia dapat bersumber pada:

- Kesulitan dalam memahami istilah.

Kesulitan ini timbul karena kebanyakan siswa hanya hafal akan istilah dan tidak memahami dengan benar maksud dari istilah yang sering digunakan dalam pengajaran kimia.

- Kesulitan dalam memahami konsep kimia.

Kebanyakan konsep-konsep dalam ilmu kimia maupun materi kimia secara keseluruhan merupakan konsep atau materi yang berupa abstrak dan kompleks, sehingga siswa dituntut untuk memahami konsep-konsep tersebut dengan benar dan mendalam.

- Kesulitan perhitungan.

Sering dijumpai siswa yang kurang dapat mengaplikasikan rumusan perhitungan kimia, hal ini disebabkan karena siswa tidak mengetahui dasar-dasar matematika dengan baik.

Oleh sebab itu, seorang guru mata pelajaran Kimia diharapkan mampu menyajikan materi-materi kimia dengan lebih menarik dan penuh inovasi salah satunya dengan mengembangkan metode pembelajaran sedemikian rupa sehingga tujuan pembelajaran dapat dicapai dengan maksimal dan agar anggapan siswa yang keliru tersebut dapat ditepis bahkan hilang sama sekali

\section{Karungut}

Karungut berasal dari kata karunya yang diambil dari bahasa Sangiang dan bahasa Sangen/Ngaju Kuno. 'Karunya' berarti tembang. Puisi tradisional atau puisi rakyat yang dikenal di Kalimantan Tengah ini diwariskan oleh nenek moyang mereka dalam bentuk lagu dan syair yang disusun sendiri oleh penciptanya, sepanjang tidak menyimpang dari kaidah yang telah dianggap baku. Di awal perkembangannya, bahasa yang digunakan dalam karungut adalah bahasa Sangen (Ngaju Kuno), tapi kini sangat jarang dipergunakan lagi. Dahulu salah satu fungsi karungut adalah sebagai media pengajaran. Karena seorang balian (guru atau dukun) menyampaikan pengajaran kepada para muridnya dengan mengarungut. Sementara para muridnya menjawab atau melaksanakan perintah dari gurunya dengan mengarungut pula. (Kebudayaan, 2017)

Sejak pertama kali karungut mulai dikenal oleh masyarakat Ngaju di Kalimantan Tengah hingga perkembangannya saat ini, telah terjadi penyebaran karungut yang dilakukan dengan berbagai cara. Dahulu penyebaran dilakukan dengan cara migrasi dari satu daerah ke daerah lain, atau melalui perkawinan antar-kelompok subsuku/suku yang berbeda. Namun dewasa ini 
pendokumentasian, pertunjukan dan perlombaan dijadikan pula sebagai media untuk penyebaran karungut. Dahulu karungut merupakan karya budaya yang dimiliki secara kolektif. Para pencipta karungut yang menciptakan karungut secara spontan tidak pernah mencamtumkan namanya. Namun setelah dikenalnya budaya tulis dan rekaman secara elektronik, para pencipta karungut mulai mencantumkan namanya.

Penyair-penyair karungut tidak lahir dari pendidikan formal, juga bukan dari proses pewarisan yang dilakukan secara terstruktur dari generasi tua ke generasi muda. Kemampuan menulis/menciptakan dan melantunkan karungut berlangsung secara alamiah yang didorong oleh keinginan untuk mencoba-coba, meniru dan belajar dari orang-orang tua. Dalam perkembangannya kini proses pewarisan secara tidak langsung pun telah dilakukan. Para penulis maupun perekam karungut ada yang telah memublikasikan karya-karyanya secara luas, melalui media cetak dan elektronik. Di wilayah pedalaman pun, warga masyarakat yang gemar berkarungut belajar dengan cara menirukan tuturan karungut melalui radio. Dengan demikian dimungkinkan terjadinya pengembangan dan perubahan karungut dari bentuk asalnya.

Hingga saat ini karungut masih dituturkan dengan menggunakan bahasa Ngaju, baik oleh orang Ngaju sendiri ataupun orang di luar Ngaju yang telah mengusai kebudayaan dan bahasa Ngaju dengan baik. Dahulu pelantunan karungut diiringi dengan musuk pengiring berupa kacapi (kecapi) bersenar dua dan tiga. Namun dalam perkembangannnya, musik pengiring karungut semakin beragam. Selain kacapi, terdapat pula katambung (sejenis tifa), gendang, gong, reba, seruling dan sebagainya. Fungsi instrumen ini semata-mata hanya untuk menyemarakkan pelantunan karungut. Orang yang menuturkan karungut disebut pengarungut.

Mereka dapat digolongkan menjadi dua kelompok, yakni: 1) Pencipta (penyair) adalah mereka yang mampu menciptakan karungut dan pasti memiliki kemampuan untuk melantunkan karungut hasil ciptaannya sendiri ataupun ciptaan orang lain. 2) Pelantun hanya bisa melantunkan karungut, tetapi belum tentu dapat menciptakan syair-syair karungut dengan baik.

Tema-tema yang digarap untuk sebuah karungut biasanya berkisar tentang kejadian atau peristiwa dalam kehidupan sehari-hari. Berdasarkan isi syairnya, karungut itu bisa dikelompokkan menjadi beberapa jenis, di antaranya: karungut cinta, karungut dongeng atau pemujaan terhadap seseorang tokoh/benda/tempat dan karungut nasihat. Berdasarkan proses penciptaannya, karungut dapat dibedakan menjadi dua kelompok besar, yaitu: 
- Karungut spontan (tradisional) adalah karungut yang tercipta secara spontan bersamaan dengan ketika syair-syair lagu itu dilantunkan oleh pengarungut. Si pencipta tidak menyusun konsep atau gagasannya secara tertulis, karena syair-syair karungut itu langsung mengalir dari pikiran dan perasaannya saja saat ia sedang mengarungut.

- Karungut tak spontan (modern) adalah karungut yang tercipta secara tidak spontan. Si pencipta menulis dahulu syair-syair yang akan dilantunkannya. Karungut yang dilantunkan bukan oleh penciptanya sendiri juga bisa dikategorikan sebagai karungut tak spontan. Jenis karungut tak spontan terdiri dari dua bentuk, yakni karungut tertulis dan rekaman. Mengingat di masa kini telah banyak pencipta dan pelantun karungut yang merekam karungut dalam bentuk kaset, CD atau alat rekam elektronik lainnya. (Kebudayaan, 2017)

Namun demikian tidak terdapat perbedaan yang esensial antara karungut spontan (tradisional) dengan karungut tak spontan (modern), baik dari pola bentuk, struktur, lagu maupun tema. Tidak pula ditemukan adanya beragam versi karungut berdasarkan wilayah atau dialek, karena penuturan karungut selalu dilakukan menggunakan bahasa Ngaju dialek baku (Kapuas-Kahayan).

Sebagai sebuah karya sastra, unsur-unsur musikal karungut ditentukan oleh beberapa unsur bunyi, yakni unsur bunyi yang ditimbulkan oleh bentuk, tuturan dan instrumen. Unsur yang ditimbulkan oleh bentuk ditentukan oleh pola pembaitan dan pembarisan, pola suku kata pada tiap baris, pola persajakan, pola perulangan (kata, frase, baris, bait). Pola pembaitan karungut terdiri atas 4 larik atau baris. Setiap baris rata-rata terdiri dari 4-7 kata atau 8-14 suku kata. Setiap bait bersajak akhir sama. Sebuah karungut paling sedikit terdiri dari satu bait dan paling banyak 34 bait. Durasi penuturannya rata-rata 15 menit.

Karungut memiliki beberapa fungsi, yaitu: 1) Media ekspresi estetik pengarungut dan masyarakatnya. 2) Media pengajaran. 3) Media bagi seorang ibu untuk meninabobokan anaknya. 4) Media untuk menghibur diri, memberi semangat, mengurangi kebosanan dan kelelahan pada saat sedang bekerja. 5) Media untuk membangkitkan semangat kebersamaan saat bergotong royong. 6) Media hiburan di saat pesta/perayaan. 7) Media untuk menyampaikan pesan pembangunan. Saat ini fungsi karungut yang paling dominan adalah sebagai media hiburan dan ekspresi estetik pengarungut. (Kebudayaan, 2017)

\section{Implementasi penggunakan pembelajaran kimia serta pendidikan karakter Peserta Didik}

Kesenian Karungut sangat dikenal oleh suku dayak Kalteng. Di 
sepanjang jalur sungai Kahayan, Katingan, Rungan Manuhing, Barito dan Kapuas, Karungut dikenal populer oleh masyarakat sekitar. Popularitas Karungut di sepanjang jalur sungai-sungai tersebut karena Karungut tidak lagi hanya sebatas ditampilkan dalam sebuah ritual melainkan sudah mudah ditemui pada berbagai macam acara hajatan seperti perkawinan, khitanan, penyambutan tamu penting, bahkan dalam acara kampanye. Seni Karungut kemudian menjadi turun temurun karena para ibu menyanyikan dan melantunkannya ketika menidurkan putra dan putrinya, sehingga sejak masa kecil masyarakat Kalteng telah terbiasa mendengarkan Karungut.

Tentu saja, Karungut tidak dilantunkan dengan menggunakan bahasa Indonesia melainkan dengan bahasa dayak Kalteng. Bahasa yang digunakan dalam Karungut adalah Sangiang. Bahasa Sangiang memiliki nilai sastra yang sangat tinggi di Kalteng sehingga dijadikan bahasa wajib saat suku dayak menggelar upacara adat dan ritual untuk berkomunikasi dengan roh halus. Tidak hanya dalam upacara adat, Karungut juga ditampilakan di dalam berbagai acara keagamaan, seperti syukuran pernikahan.

Kemudian, Karungut merupakan kesenian tradisional di Kalimantan Tengah yang sudah populer di tengah-tengah masyarakat. Karungut juga dapat dikatakan sebagai kesenian tradisional yang komunikatif karena pesan yang dikandung di dalaam pantun menggunakan bahasa yang mudah dimengerti oleh seluruh lapisan masyarakat. Oleh karenanya, kesenian Karungut ini memiliki makna yang sangat mendalam di hati masyarakat Kalteng ketika kesenian ini dipertunjukkan. Kecintaan masyarakat terhadap Karungut membuat mereka sadar untuk terus menjunjung tinggi kesenian asli Kalteng ini. Karena bagaimana pun, dalam pandangan masyarakat, kesenian ini merupakan seni khas Kalimantan Tengah yang mempunyai arti dan makna yang sangat dalam untuk ritual dan penyampaian nasihat.

Selain itu, kesenian Karungut tidak hanya dilantunkan melalui lisan semata, tetapi juga diiringi dengan tarian-tarian seperti tari manasai Karungut, tari Karunya, tari Tandak Mandau dan tari Deder. Pun demikian, Karungut juga tampil bersama alat musik tradisonal maupun modern seperti telah disebutkan sebelumnya, dengan tujuan agar Karungut terdengar semakin syahdu serta mampu menyesuaikan dengan perkembangan jaman. Alat musik modern macam band dan organ bahkan kini telah dijadikan alat utama untuk mengiringi Karungut. Hanya saja, alat-alat musik tersebut dianggap tidak akan mempengaruhi keaslian Karungut yang dikenal mengandung nilai sastra yang sangat tinggi dan klasik. Artinya, keaslian Karungut tetap terjaga meski harus berkolaborasi dengan 
alat-alat music modern.

Pembelajaran menggunakan karungut, mengimplementasikan penggunaan karungut dalam media pembelajaran dalam menghapalkan unsur-unsur dalam tabel periodik. Lagu yang digunakan dalam unsur-unsur tabel periodik, di terjemahkan dalam bahasa dayak dohoi sesuai dengan tempat peneliti mengajar. Setelah diterjemahkan, teks karungut tersebut di nyanyikan oleh alumni dari sekolah tempat penelitian yang menguasai kesenian karungut dan di dokumentasikan dalam bentuk video. Video tersebut di tampilkan dalam pembelajaran sehingga peserta didik lebih paham dengan video tersebut.

Selain implementasi dalam pembelajaran, pendidikan karakter dapat dilaksanakan dengan mengembangkan kultur sekolah. Tiga hal penting dan mendasar yang perlu segera diagendakan agar pendidikan karakter benar-benar bisa diimplementasikan ke dalam institusi pendidikan. Pertama, membangun keteladanan. Sudah bertahun-tahun lamanya, negeri ini telah kehilangan sosok negarawan yang bisa menjadi teladan dan anutan sosial dalam perilaku hidup sehari-hari. Kaum elite kita, diakui atau tidak, hanya pintar ngomong di atas mimbar pidato, tetapi implementasi tindakannya ibarat "jauh panggang dari api". Institusi pendidikan tak akan banyak maknanya apabila kaum elite kita hanya berada "di atas menara gading kekuasaan", miskin keteladanan, dan hanya sibuk bermain akrobat untuk mempertahankan kekuasaan semata, kedua, memberdayakan guru. Secara jujur harus diakui, profesi guru, semenjak disahkannya UU Guru dan Dosen, menjadi lebih "bergengsi” dan bermartabat.

Empat kompetensi - profesional, pedagogik, kepribadian, dan sosial yang menjadi syarat wajib bagi guru profesional belum sepenuhnya bisa diimplementasikan dalam perilaku dan kinerja guru sehari-hari. Belum lagi persoalan perlindungan dan advokasi terhadap kinerja guru yang dianggap masih lemah, sehingga guru belum sepenuhnya mampu menjalankan peran dan fungsinya secara optimal. Yang tidak kalah penting, guru juga perlu terus diberdayakan dalam soal pengembangan pendidikan karakter lintas-mata pelajaran. Artinya, pendidikan karakter bukan hanya semata-mata menjadi tanggung jawab guru PKn atau Agama saja, melainkan juga menjadi bagian yang tak terpisahkan dari kinerja guru secara menyeluruh dan terpadu. ketiga, dukungan lingkungan sosial, kultural, dan religi terhadap keberlangsungan pendidikan karakter dalam dunia pendidikan.

Di tengah situasi peradaban yang makin abai terhadap nilai-nilai akhlak dan budi pekerti, institusi pendidikan tak bisa sepenuhnya "otonom" dan berjalan sendiri tanpa "intervensi" lingkungan. Segenap elemen bangsa, mulai tokoh 
masyarakat, agama, hingga media, perlu memberikan dukungan penuh dan optimal terhadap implementasi pendidikan karakter. Media televisi yang selama ini telah menjadi "tuhan" baru di kalangan anak-anak dan remaja perlu menjalankan fungsinya sebagai pencerah peradaban dengan memberikan suguhan dan tayangan yang edukatif. Jangan sampai anak-anak yang tengah "memburu jati diri" dicekoki dengan tayangan sinetron mistik atau entertaintment yang serba glamor, hingga membuat anak-anak bangsa di negeri ini makin kehilangan pegangan dan basis pendidikan karakter dalam hidup dan kehidupannya.

\section{Simpulan}

Sumber daya lokal yang di implementasikan dalam pembelajaran kimia serta pendidikan karakter peserta didik berupa video karungut tentang unsur-unsur tabel periodik. Peserta didik lebih antusias dalam pembelajaran serta melestarikan kebudayaan lokal.

\section{Daftar Rujukan}

Depdiknas. (2003). Kurikulum Kimia 2004 SMA Pedoman Khusus Pengembangan Silabus dan Penilaian. Jakarta: Balai Pustaka.

Gino, H. J. (1997). Belajar dan Pembelajaran I. Surakarta: Sebelas Maret University Press.

Gredler, M. E. (1991). Belajar dan Membelajarkan. Jakarta : Raja Grafindo Persada.

Kebudayaan, D. (2017, 10 25). Karungut. Retrieved from Dirjen Kebudayaan Kemdikbud Web site: http://kebudayaan.kemdikbud.go.id/ditwdb/2015/12/17/karungut/

Magnis-Suseno, F. (1987). Etika Dasar: Masalah-masalah Pokok Filsafat Moral. Yogyakarta: Kanisius.

Magnis-Suseno, F. (2008). Etika Abad Kedua Puluh. Yogyakarta: Kanisius.

Mulyati Arifin. (1995). Pengembangan Program Pengajaran Bidang Studi Kimia. Bandung: Erlangga.

Nana Sudjana. (1987). Penilaian Hasil Proses Belajar Mengajar. Bandung: Remaja Rosdakarya.

Poerwadarminta, W. J. (1976). Kamus Umum Bahasa Indonesia. Jakarta: Rineka Cipta.

Slameto. (1995). Belajar dan Faktor-faktor yang Mempengaruhinya. Jakarta : Rineka Cipta.

Soejadi. (1999). Pancasila sebagai Sumber Tertib Hukum Indonesia. Yogyakarta: 
Lukman Offset.

Wiji Suwarno. (2006). Dasar-dasar Ilmu Pendidikan. Yogyakarta: Ar-Ruzz Media.

Wiramihardja, A. (2007). Pengantar Filsafat (Sistematika Filsafat, Sejarah Filsafat, Lodika dan Filsafat Imlu Epistemologi, Metafisika dan Filsafat Manusia dan Sksiologi. Bandung: Aditama. 